\title{
Electrolysed palladium has the potential to increase methane production by a mixed rumen population in vitro
}

\author{
KA Munyard 1, SK Baker 2 \\ 1 The University of Western Australia, Faculty of Agriculture, Nedlands, Western Australia, 6907 \\ 2 CSIRO Floreat Park, Western Australia, 6014, Australia
}

$\mathrm{H}_{2}$-transfer between methanogens and bacteria or fungi from the rumen have been demonstrated (Wolin and Miller, 1988, in: The Rumen Microbial Ecosystem, Hobson, ed). Methanogens attach to protozoa in the rumen and it has been hypothesised that this is a commensal relationship where the methanogens use hydrogen $\left(\mathrm{H}_{2}\right)$ generated by the protozoa (Vogels et al, 1980, Appl Environ Microbiol, 40, 608-661). Boone and colleagues (1989, Appi Environ Microbiol, 55, 1735-1741) argue that $\mathrm{H}_{2}$ cannot diffuse to the cell surface of methanogens from the rumen liquid at a rate fast enough to account for the amount of methane $\left(\mathrm{CH}_{4}\right)$ produced. When $\mathrm{H}_{2}$ was bubbled into the rumen the proportion of protozoa with attached methanogens decreased, however no estimate of $\mathrm{CH}_{4}$ production under these circumstances was made (Stumm et al, 1982, Br J Nutr, 47, 95-99). We report here preliminary findings from a study to use electrolysed palladium to provide a source of $\mathrm{H}_{2}$ for methanogens in a mixed rumen population in vitro.

Palladium $(\mathrm{Pd})$ can be saturated with up to 0.88 moles $\mathrm{H}_{2}$ per mole of metal by electrolysis (Green and Quickendon, 1994, J Electroanal Chem, 368, 121-131). Palladium as the cathode was electrolysed in $1 \mathrm{M} \mathrm{H}_{2} \mathrm{SO}_{4}$ using $200 \mathrm{~mA}$ and a platinum anode. The rate of release of $\mathrm{H}_{2}$ after electrolysis is determined by the ratio of surface-area to volume of the metal; after electrolysis for $16 \mathrm{~h}$ a $10 \mathrm{~g}$ lump of $\mathrm{Pd}$ continued to release $\mathrm{H}_{2}$ for $2 \mathrm{~h}$, whereas c.a. $300 \mathrm{mg}$ of $\mathrm{Pd}$ wire (250 $\mu$ m diameter) released $\mathrm{H}_{2}$ for only $10 \mathrm{~min}$.

Six $120 \mathrm{ml}$ serum vials containing $30 \mathrm{ml}$ ovine rumen contents were filled with $\mathrm{H}_{2}: \mathrm{CO}_{2}$ (80\%:20\%). Pd wire (162 and 177mg, $250 \mu \mathrm{m}$ diameter) was added to two of the vials, electrolysed Pd wire (283 mg and $286 \mathrm{mg} 250$ $\mu \mathrm{m}$ diameter) was added to two of the vials, and the remaining two vials were controls. The vials were re-filled with $\mathrm{H}_{2}: \mathrm{CO}_{2}$, sealed with butyl rubber stoppers and incubated at $39^{\circ} \mathrm{C}$ with shaking. The volume of gas evolved was measured and duplicate analyses were made of the composition of the gasses in the headspace at the start of incubation and $2 \mathrm{~h}$ later. Gas samples were analysed by gas chromatography for $\mathrm{CH}_{4}$ and $\mathrm{H}_{2}$ using a carbosphere column, a thermal conductivity detector and argon as the carrier gas.

At the beginning of the incubation there was no detectable $\mathrm{CH}_{4}$ and the average concentration of $\mathrm{H}_{2}$ was $45.1 \mu$ moles $/ \mathrm{ml}$. After $2 \mathrm{~h}$ there was no significant difference $(\mathrm{p}<0.05)$ in the concentration of $\mathrm{CH}_{4}, \mathrm{H}_{2}$ or the ratio of $\mathrm{CH}_{4}: \mathrm{H}_{2}$ between the control and nonelectrolysed $\mathrm{Pd}$. Replication in the two vials containing electrolysed Pd was poor; the concentrations of hydrogen in the headspace gasses were similar but the concentration of $\mathrm{CH}_{4}$ in one vial was double that in the other. This suggests that electrolysed $\mathrm{Pd}$ provides $\mathrm{H}_{2}$ that is more easily accessed by the methanogens than the $\mathrm{H}_{2}$ in the gas headspace. Analysis of the surface of the electrolysed Pd from both vials by scanning electron microscopy revealed a coating of nickel on the surface of the Pd in the vial with the lowest $\mathrm{CH}_{4}$ concentration. This piece of $\mathrm{Pd}$ wire had been electrolysed in an earlier experiment using a stainless steel anode. Since repeated electrolysis reduces the amount of $\mathrm{H}_{2}$ that can be absorbed by Pd (Green and Quickendon, 1994) this may explain the difference in methane production in the two vials.

These data indicate the potential to use electrolysed $\mathrm{Pd}$ as a source of $\mathrm{H}_{2}$ for methanogens in vitro. The value of electrolysed $\mathrm{Pd}$ for an in vivo study of interspecies $\mathrm{H}_{2}$ transfer will be the subject of further investigations.

Concentration $(\mu \mathrm{moles} / \mathrm{ml})$ in the headspace (mean $\pm \mathrm{SD}$ )

Time ( $h$ ) from the start of incubation Control Palladium Electrolysed Pd (used) Electrolysed Pd (new) Methane

(2)

$5.4 \pm 0.02$
$5.9 \pm 0.95$
5.3
12.6

Hydrogen

$\begin{array}{cc}39.0 \pm 0.05 & 0.14 \\ 55.5 \pm 12.8 & 0.11 \\ 35.6 & 0.15 \\ 28.3 & 0.44\end{array}$

$\mathrm{CH}_{4}: \mathrm{H}_{2}$

0.14

0.15 